\title{
Adaptable Landscapes in Housing Renovation: A Tool for Activating Local Territorial Communities
}

\author{
Gintaras Stauskis, Vilnius Gediminas Technical University
}

\begin{abstract}
Based on the basic theoretical principles and the existing practices of community involvement into planning, the article explores the ways of improving urban landscapes of residential territories, especially in the process of housing renovation. Researchers of different countries increasingly focus their attention on adaptability of landscape in the process of housing renovation and identify the main actors in this process. Local communities are strongly motivated players in the process of improving residential areas, providing the planners and architects with the ideas for programming, designing and implementing diverse housing projects on different scales. At the same time, the local communities themselves get strengthened by consolidating their interests towards achieving common goals in the territory of their interest. Housing renovation process is a perfect sphere where local communities could express their goals of improving living standards in the existing area of residence. The main interest areas of local residents for better living space and the surrounding area are presented, where landscape is seen as an important consolidating element. As a physical resource, landscape is important for local communities for its recreational function in a close environment also in connection to wider urban landscape.Providing green links for the residents among local, urban and suburban areas is a way to develop an integrated landscape system. As a visual element, landscape has an impact on visual identity of the residence that is perceived and memorised by residents. The article gives a set of recommendations on the ways of improving the methods and practices of complex urban renovation underlining community-based landscape development plans.
\end{abstract}

Keywords - Architecture, community involvement, housing renovation, landscape, local community, urban planning.

Tradition of community involvement into urban planning practice is a widely acknowledged scientific method and a local policy measure used to acquire the public essence of planning and reshaping urban territories. In different countries, it accounts for several decades and has multiple formal and informal implementation layers. Initially being a tool to minimise inevitable risks of community opposition to different types of planning projects, it has gradually evolved into a complex tool applied for visioning, programming, conceptualising, implementing and monitoring diverse urban development projects. Communities with longer experience and deeper tradition in public participation have developed complex systems of expressing their interests by participating in urban and regional planning processes. The tradition of local governance in the UK has developed the common guidelines for organising and presenting a statement of community involvement [11] with the detailed description of the main phases, procedures and the expected outcomes of this process, whereas each local authority adjusts it to the local needs and interests by shaping an activity program for a particular community [8]. The existing legislation has paved a road for developing more confident application practices in Lithuania. Recent practices apply public involvement to different project phases ranging from program generation to concept development, detailed technical design, implementation, supervision and maintenance [5]. Application of these techniques with the emphasis on landscape development in housing areas is the focus of this article.

\section{Recent Research on Public Involvement in Housing RENOVATION}

The problem of remodelling the existing housing areas is widely discussed by researchers of different countries. The basic success of urban planning and design in all historical periods has been supported by public needs and community interests, and especially in the recent period of globalisation and loss of regional face the results of urban policies are strongly dependent on the input from local communities [2], [15]. The concept of a city as a system of landscape presents a completely different perspective for modern urban development [12]. Architectural instruments that could be applicable to renovate, reconstruct and refurbish the still existing residential blocks from different periods of time are widely analysed by the researchers of the Baltic Sea Region. The tradition of affordable housing was developed in many European countries. It was based on the principles of rigid functional zoning which was because of its shortages later changed by the policy of integrated urban development [1]. Landscape as an important factor of life quality and a key element in spatial composition of residential territories should be treated extremely carefully while updating the existing urban blocks from the second half of the $20^{\text {th }}$ century. The inefficient energy use is a strong but not the only and even not the most important driver for renovating these areas. In opinion of the residents, there are numerous aspects connected to planning and technical installation of residential space that are prioritised and important for the local communities [3]. An increasing number of vehicles and the uncontrolled chaotic mobility, especially in Lithuania, have turned residential areas into motorised jungles with little green space and a lot of black pavement. Therefore, development of sustainable mobility with consequent application to recreation is another challenge [9]. As noted by I. Urbonaite, local communities have a great interest and direct impact on different elements of recreation system that are developed in housing areas on the basis of existing natural resources and especially on those that are located in short distances from the dwellings [16]. Different forms of public approaches are practised in Europe from more formal as public involvement into selected processes to more sophisticated as participatory planning with different effects on a final result, which is usually indicated in the quality of living. The review of recent research clearly notes that involving public into the planning processes is a good, well-experienced and reliable tool to improve the plans and 
to achieve better predictable and more socially acceptable results for residential and the other areas of a city and its surroundings.

\section{Legal Framework and Practice of Public Involvement}

Regulation on community information about territorial planning [14] issued by the Ministry of Environment of Lithuania in 1996 with numerous amendments requires public consultations to be taken at several phases of planning performed at different territory scales. The basic principles of public involvement into planning and architecture activities are encoded in the national directive on the development trends of architecture [6] and those of landscape [7]. The real meaning of "public" differs depending on a level of planning: at the national and regional level it is associated with the residents of a country or a region. At the municipal level, it corresponds to the municipal citizens and at the local level it involves residents of local communities. The Regulation requires informing the public about the initiated plan, presenting the general goals of socioeconomic and environmental priorities to the public as well as presenting a completed planning project on a public exhibition that should be followed by a public meeting where proposals from citizens are accepted, analysed and communicated. In addition, all planning projects after their approval are registered in the National Planning Register and publically accessible upon the demand.

The disclosed legal framework is adequate and up-to date compared to a modern national tradition across many European countries. It gives an action space in the planning process for all the main stakeholders. Still the short practice of its application results in the poor experience and status of the civil society in general. Although the legal requirements were imposed just 15 years ago, the experience of different parties in this process is very short. The increasing number of participants in public discussions, as well as the number of proposals and appeals for various planning projects indicates that different stakeholder groups are gaining more experience quite fast. The previously passive residents gain additional motivation for the next planning initiatives if a planning result negatively impacts city landscape and especially the close residential environment. The way from the absolute passiveness, which is one margin, later often goes to hyper-activity, which is the other margin. Indifference to some development projects some years ago has recently given a place to active and often critical actions of specially organised citizens' groups. Some important projects meet a strong opposition and the obstructive actions usually delay the planning process, which is anyway quite lengthy mostly because of numerous bureaucratic procedures. The time of around one year is usual for passing all procedures of a detail plan and sometimes this time extends for up to three years.

When the public gets organised into interest groups it can transparently manifest its interests as very clear needs for the close and more remote urban environment. When more experience and knowledge are accumulated, the wide swing of an activity scale calms down from marginal to optimal and stays on a generally acceptable interval that reflects the dynamism of social life in the country or city, in this case the city of Vilnius in Lithuania. The community interest in an ecological and healthy environment with good options for recreation is especially sensitive in residential areas as a major indicator of quality of life. These trends are analysed in more detail in the studied cases of Vilnius.

By the tools of anthropologic, environmental, economical, technical and synthesising urban analysis, the local territorial communities could be identified in urban structure as the spatial clusters of residents with common interests in a particular area [5]. The groups of these interests have a universal and specific character reflecting the basic values of the public of a particular area. This data has to be identified and recorded to start the public dialogue. Initial opinions of residents towards the present state of housing area provide the planners with the information about physical, aesthetical and environmental quality of buildings and spaces, the quality of social services (public administration, primary child and health care, education) and infrastructure (mobility and technical supplies), environment quality and landscape in particular. The system of public values and proposals along with results of professional urban analysis provides the basic programme for the planning project.

\section{Policy Measures for Landscape Improvement in Housing RENOVATION}

The list of policy measures on landscape that has been adopted by the Ministry of Environment of Lithuania presents the basic strategies for changing natural and cultural landscapes. The document states unsatisfactory condition of planting systems in urban landscape. The landscape features and specific traits that are scientifically validated and socially accepted for the particular territorial units are recognised as the basic quality indicators for the further development of landscape system in Lithuania [7]. This strategic principle encodes integration of the researchers and the communities into the process before any landscape alteration could happen by involving communities into validation of scientifically formulated principles. The role of municipality, which in many cases is the leading watch-dog in this concept, is omitted and could be reasonably accepted just as a social moderator.

Involvement of the both abovementioned parties in Lithuania and in the neighbouring countries is quite a specific issue because of differences in research on the one hand and community life on the other. To a great extent, the presented research is an attempt to facilitate the first line of involving the scientific analysis tools into the development and redevelopment of landscape in different areas - urban, suburban or rural. In Lithuania, planning is organised at the national level, regional level, and local level with the different outcomes - the national development plan, regional general plan or municipal master plan. Being organised by different institutions (the national government, the ministry or the municipality), the plans of different levels also have different impact tools on the analysed landscape systems. The national development plan sets very general strategies based on balancing environmental, social and economic conditions and it does not interfere into more detailed solutions of a local level. Public involvement could play a positive role at this level while setting the national and regional policies and development priorities. The general plan of a region (a county or an administrative district) sets the development lines for the big territories that consist of several municipalities. At this level, the basic development principles are 

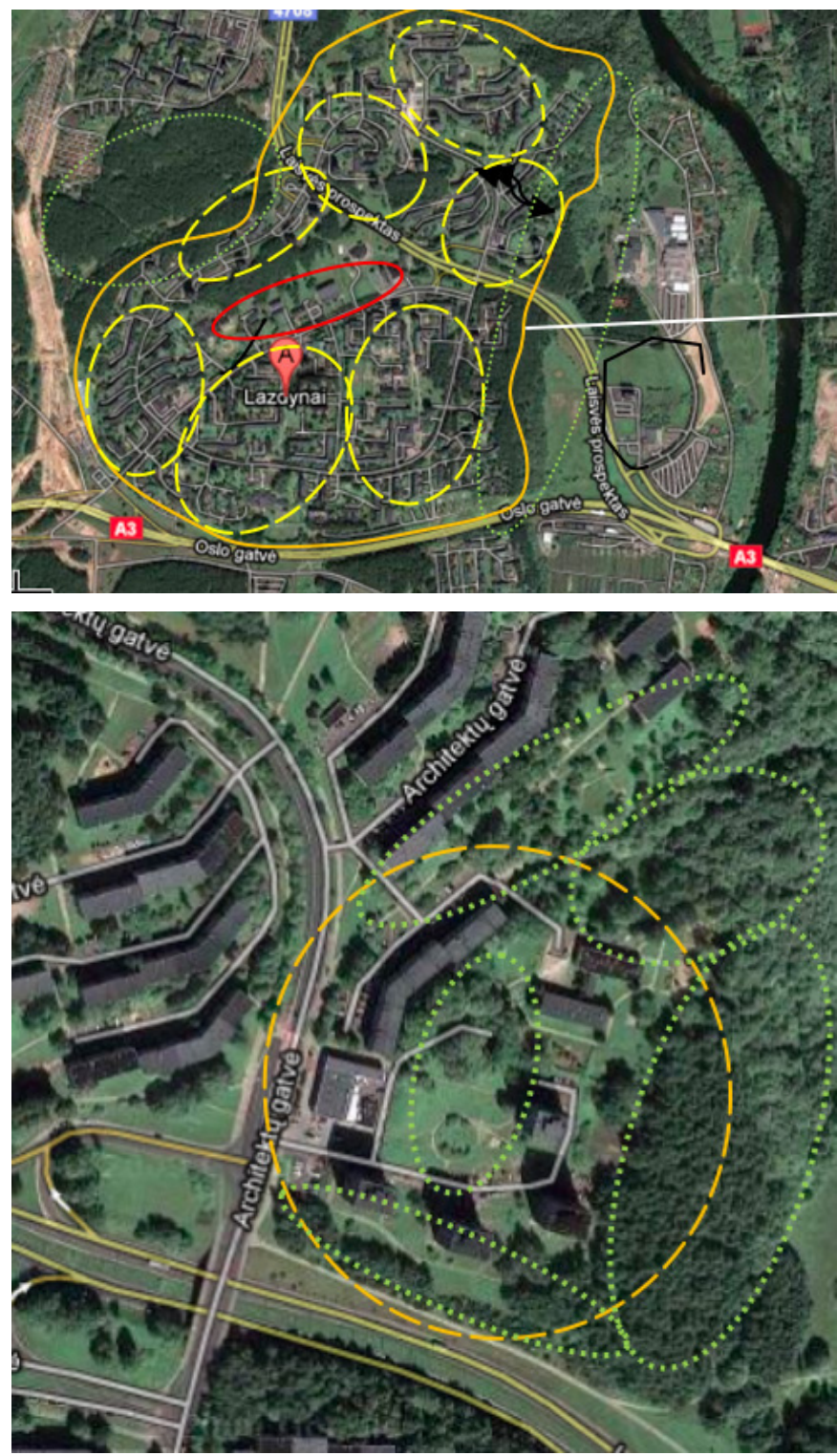

Fig. 1. Housing district "Lazdynai" in Vilnius. Planned and developed in 19701975. Structure of the local micro-districts (a); the local neighbourhood with landscape elements in its close environment (b).

determined by planning spatial development of urban and rural areas in close connection with natural values, social interest and infrastructure. Public could efficiently support the planners at this phase by providing them with useful information about the problems and the preferred outcomes.

At the level of municipality plans, more detailed solutions are provided for achieving a more integral and compact urban tissue and more liveable cities. At this level and especially while detail plans for smaller municipal territories are developed, the basic solutions for residential areas are generated to be implemented at the last phase of planning - technical design. At this phase, public involvement is most needed and is mainly efficient as it could impact the particularly important and systematically coherent solutions. The last but not the least important planning phase is technical design, i.e., setting the concrete measures for a site, apartment and its interior. It deals mostly with the owners or the developer and has a little impact on the solutions of a common environment.

\section{IdENTIFICATION AND LAyout of COMMUNity InTERests in Housing Areas}

The intake that could identify a community also differs depending on a territorial level of planning and its margins and needs clearer identification for the overall success of the project. In general, the intake of a community should correspond to the territorial level of a plan: on a national level the plan should involve the population of the whole country, which should be named as a society; on a regional scale planning should be judged by residents of a region and the surrounding regions; on a municipal level the community should clearly cover the residents of an urban area with its suburban districts; and on a local level when part of municipality / city is planned this should be a represented group of local residents. Having discussed the role and scope of a community in this point, it is appropriate to talk about the scope of planning as an area. The planning project that covers just a single land plot or a very small group of plots would get into difficulty to identify the group of residents interested in this project. Planning regulations could solve this problem on a formal level requiring the direct involvement of people who live within a certain distance, or on the same street, or in another formal way. In this situation, the selection of interested parties will be just formal and will hardly represent a real community interest. The social unit that has a real informal identification is a local territorial community or a local neighbourhood. In both cases, these are groups of residents that are connected by common interests expressed in a particular urban area. The methods of their identification differ depending upon urban tissue, mode of planning, historical tradition and should be selected individually depending on a particular case [5].

In the case of Lazdynai residential area in Vilnius (Figure 1), the district was planned as a homogenous living area with a certain specific structure that reflects habits, fashions and regulations of that time. The main structural unit in this area is a micro-district. In Lazdynai case, the area has seven micro-districts and the public centre interconnected by local streets and pedestrian walkways. The local territorial community could logically be traced in the boundaries of a single micro-district. In its turn, a micro-district is formed by the groups of houses that consist of separate blocks of flats. The group of houses in different cases has a common area for development, recreation, playgrounds, parking and the other common amenities and, therefore, could form a smaller structural part of a micro-district called a neighbourhood. In many cases, a neighbourhood as a group of several blocks that are composed in a single territory and have common use elements in a common use area is a proper border line for involving its residents into any project that deals just with a single block of apartments. It is evident that in a case similar to Lazdynai residential area, any renovation activity that would deal just with a single house would affect the other residents in neighbouring blocks as well. In the case of a micro-district, the residents of one micro-district should be interested in the development or redevelopment of common public areas, including landscape of the whole micro-district. On the other hand, the interest of all residents in activities around 
one block would be quite limited as they would have a limited dependency and connection to the surroundings of a single block of flats.

In spite of territorial and structural differences, the basic groups of interests that citizens have in such residential areas as Lazdynai and several others in Vilnius could be identified and structured in several basic groups, starting from a smaller territorial scale and moving to a big scale. Based on the opinion of residents, in a priority order they are as follows:

- quality of an apartment occupied;

- quality of the whole block where the apartment is located;

- quality of a close surrounding area (playgrounds and facilities for children and teenagers, daily recreation, parking, adjacent plantings);

- quality of services in a local district centre (shopping centres, cafes, fitness centres, household services);

- quality of a more remote but easily accessible environment (public transport, adjacent landscapes, parks, sport fields);

- quality of a remote urban environment - mostly city centre (city centre, remote landscapes as parks and other resources).

This sequence is rationally based on factors of frequency of need and intensity of visiting. The most important elements are the ones of daily need (every day, several times a day), such as a dwelling itself and its close surrounding. Elements in urban territory of periodic use (every second day, a few times a week) are on the second level of importance. And those of episodic use that are accessed once a week or several times a month are on the third level of importance. Certainly, the system is more integrated than this structural scheme may show. Still this is a good way to identify a community size area on the one hand and the range of spread of their interests on the other. In this situation, a neighbourhood and a local community of a micro-district would correspond to the daily need area, the whole residential district would cover most periodic needs of the residents, and the city or its big part (the Old Town, the New Town) would be a space for meeting the episodic interests of residents. The ranges of intake areas for community involvement should correspond to the coverage of interests that the residents have.

According to the renovation project of the five-storey residential block in Lazdynai residential area (Figure 1a), the analysis of a site reveals that a group of six buildings forms a territorial unit, which could be identified as the local territorial community (Figure 1b). The territory comprises four residential blocks, one moderate size shop and a large kindergarten located in a clearly outlined space between the big forest massif and groups of local plantings. All together these elements form a capacity to meet the daily needs of the residents with the average number of 500 residents in 240 apartments. The urban unit was planned in 1970 as a five-storey 30-apartment unit that was duplicated and extended to form a linear block with a few breaks that successfully followed the relief character on the site (Figure 2). The renovation project includes technical improvement of the building by covering the outer walls and roof with insulating shell, changing and modernising the engineering systems of common and individual use, also improving planning of the apartments where necessary (Figure 3a). The latter attempt demonstrates adding a balcony area to the
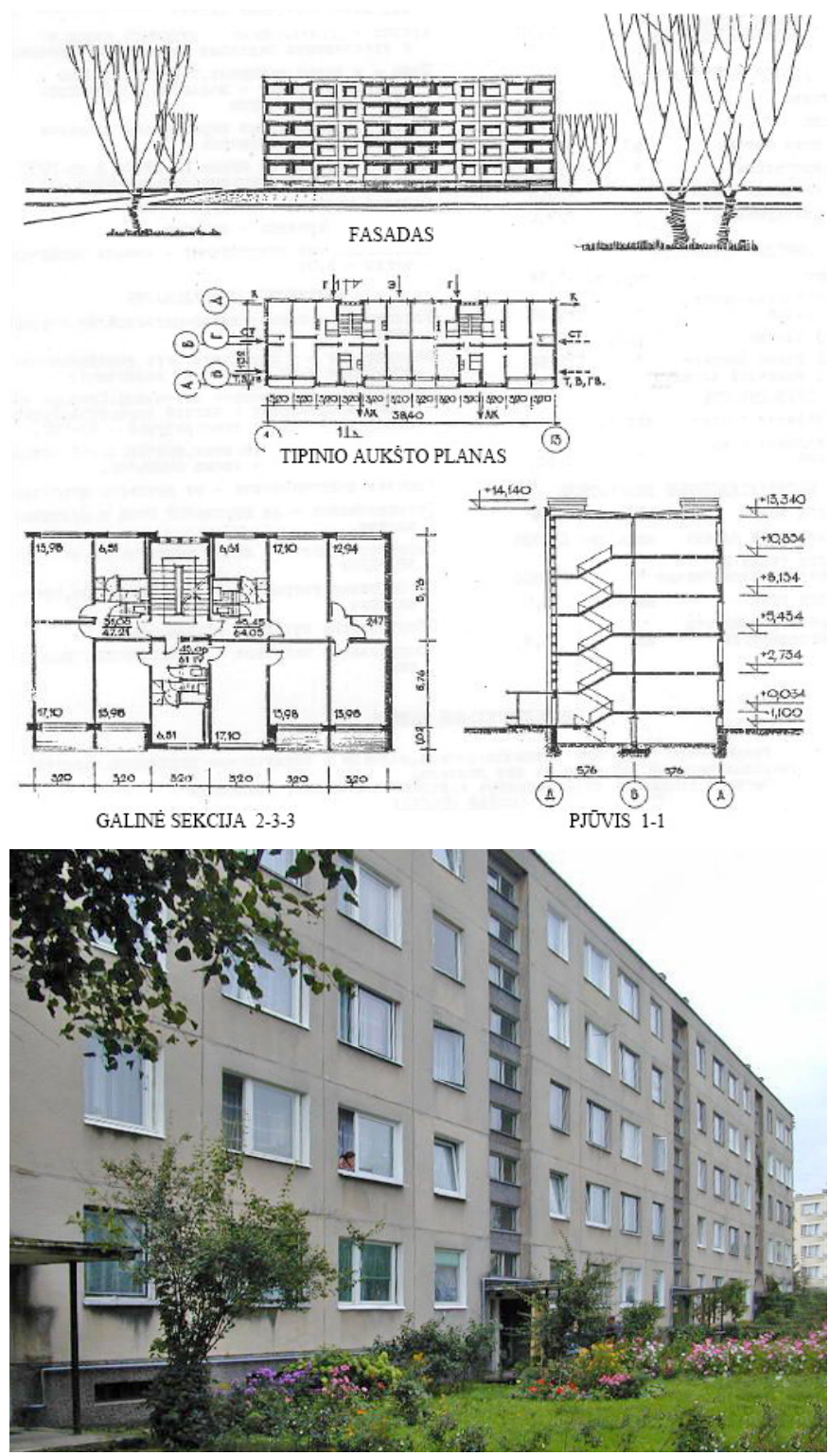

Fig. 2. The existing 5-storey prefabricated panel housing block of 30 apartments at Architektu Str. 212 in "Lazdynai" residential area (Vilnius) is planned to be renovated. The original project from 1970 (a); the present view, 2011 (b).

space of a living room and, thus, increasing the useful space of an apartment. This proposal meets the interests of the residents as more living rooms will be more spacious. Simultaneously, the proposal of exploiting the balcony space more intensively by incorporating it into the living area of an apartment provides residents with more contact with the surrounding landscape in a visual way. The plantings of the surrounding forest and smaller groups of trees inside the community space have a great potential of recreation and overall living comfort. As the maintenance of landscape elements in the area over the past four decades has been very poor, the basic concern about the local landscape as a physical resource is to improve its physical quality and landscape composition on the one hand and to preserve it as a valuable system on the other hand. There are numerous problems that have appeared during the use time and that have to be resolved in the 

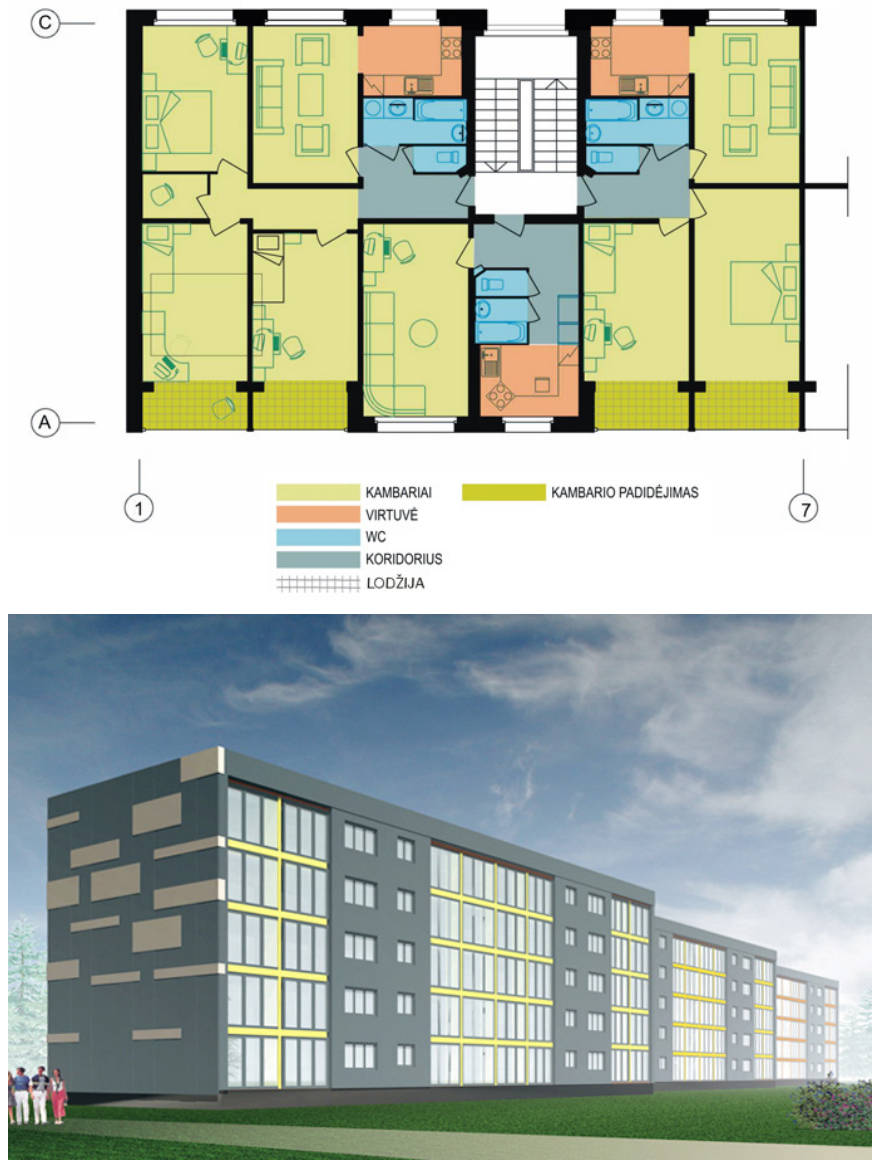

Fig. 3. The renovation project for the housing block on Architektų Str. in Vilnius. The plan (a), the view (b).

same renovation process in the community area as identified in Figure $1 \mathrm{~b}$. The worn-out technical infrastructure, lack of parking space, need of new playgrounds and sport fields as well as need to shape and maintain the local plants are the main ones. The architects are in a situation to meet the mentioned interests of local community by coherent, balanced and aesthetically original planning and design solutions.

\section{The Way towards Better Landscape in Housing Renovation AREAS}

On the level of a project programme, the involvement of local communities is inevitable as an absolute majority of residents are the present owners of an apartment stock. On the other hand, this additional social energy could and should give the architects additional knowledge and inspiration to create individual, socially conscious and architecturally valuable solutions for renovating recently dullblocks and turning them into a modern multifunctional urban space. The principle of correspondence between the range of territorial interest of a certain territorial community and the recommended intake area for public involvement is a guiding principle in this process. Based on the research aspects presented herein, it is strongly credible that involving the public especially in a way of structured representation would increase attractiveness of a national housing renovation programme in Lithuania that is currently suffering from absolute public neglect.
Different tools of urban design could be empowered to achieve the abovementioned goals. The efficient use of urban territory might be achieved by densifying the existing development to fill the void parts of a plot and to give it more urban expression. The residents of the housing areas from 70s are suffering from mono-functional disintegrated development with low options for all types of services, labour and the social life. The new local small business development could be a step forward to solving this problem by bringing additional power to local residential districts. For this reason, installing different services provided by small and medium enterprises preferable with the interest of local residents is one more strategic goal.

The pilot area that is presented herein has real treasures of natural environment as extensive plantings on an expressive relief that give a face to the whole area. Therefore, the elements of natural and created landscape should be protected and preserved in the process of renovating these blocks to serve the residents in a new quality and shape. It would be an awful mistake and great loss if trees were sacrificed to extending parking plots or other engineering systems. On the contrary, landscape elements as powerful space formants should be used to emphasise the space of local territorial community on the one hand and reduce unnecessary through-passes on the other hand.

Based on the personal experience of housing design, the author can give proof that a typical face of all the blocks developed in Lazdynai residential area as well as in the other districts of mass housing was determined by application of the same standard housing projects with just 2-3 versions of row-blocking and height, whereas the options for architectural finishing and design were almost limited to none. This resulted in quite a similar and often monotonous picture of the entire residential districts. The housing renovation process is a perfect instrument to bring more architectural originality to the areas. Clearer individual identification of local community as a typical area would bring the architecture to a more social level.

It is high time for the process of renovation to improve the gaps of social infrastructure in the area. The elder residents and people with disabilities constitute a big part of residents. In this context, renovation as a complex process should bring more accessibility to the areas as well as to the apartments. According to Lithuanian regulations, 5\% of apartments in a planned area have to be accessible for people with disabilities. In the case of the analysed local community in Lazdynai, it would make around 12 apartments. Locating them all on a ground floor and providing smooth access might be one option. This aspect requires more humanisation actions in the area of re-planning pedestrian walkways, cycling lines, parking, including space for the disabled and the other elements of a site. Mobility elements inside the residential area should be developed with care to protect green space and to give priority to sustainable mobility solutions by prioritising pedestrian movement and cycling throughout the area and connecting it to the main interest routes in the residential district and beyond [9]. The car driving space should be localised closer to the entrance to the area and limited by visual and functional means. Innovative parking solutions could be analysed and applied. 
The next necessary action in humanising the residential area would be adding primary health care units located in reasonable reach ranges to this community area. Primary health care as a basic indicator in a health care system should be facilitated from a primary level where family care is an essential thing [10].

\section{Conclusions}

Public involvement in residential areas should be treated in research and professional practice as an important generator of quality solutions to improve functionality and aesthetics of the space. It should be organised minding the interest areas of residents' groups. Empowerment of local territorial communities should be extremely fruitful in this process.

Renovation as a complex process should be used to analyse and resolve different problems that have occurred during the half-century use time of the majority of soviet-period residential areas. In this context, landscape should be used as a central interest area and a platform for improving infrastructure and the technical state of the housing areas as well as forming their coherent and modern outfit.

Improvement of spatial organisation of existing landscape resources should be executed by close citizens' involvement that could provide the professionals with the basic information for sustainable and viable solutions.

\section{REFERENCES}

1. Džervus, $\mathbf{P}$. The origins and directions of large scale post-war residential districts. Science - Future of Lithuania, Vol. 3 No. 3, 2011, p. 11-15.

2. Hackney, R. The Good, the Bad and the Ugly. London: F. Muller, 1990. $224 \mathrm{p}$.

3. İle, U. Landscape composition development stages in multi-storey residential areas of the Baltic Sea region. Science - Future of Lithuania, Vol. 3, No. 3, 2011, p. 16-22.

4. Europos kraštovaizdžio konvencija (European Landscape Convention and Explanatory Report) [online]. Lietuvos Respublikos aplinkos ministerija [cited 31.05.2012.]. http:// www.am.lt/LSP/files/krast-konv.pdf ISBN 9955-499-01-x. P. 5

5. Jakaitis, J., Stauskis, G. Identification of Informal Territorial Communities in the Urban Structure of Vilnius City. International conference „Environmental engineering “. Vilnius: Technika, 2011, p. 913-917.

6. Lietuvos architektūros politikos krypčių aprašas. Lietuvos Respublikos Vyriausybès 20050518 nutarimas Nr. 554 [online]. Lietuvos Respublikos aplinkos ministerija [cited 09.04.2012.]. http://www.am.lt/VI/article. php3?article_id=5553

7. Lietuvos kraštovaizdžio politikos krypčiu aprašas. 2004. Lietuvos Respublikos Vyriausybės 20041201 nutarimas Nr. 1526 [online]. Lietuvos Respublikos aplinkos ministerija [cited 09.04.2012.]. http://www.am.lt/VI/ article.php3?article_id=5044

8. Sheffield Development Framework. Statement of Community Involvement. [online]. Sheffield City Council, 2006 [cited 09.04.2012.]. https://www. sheffield.gov.uk/dms/scc/management/corporate-communications/ documents/planning/SDF/Statement-of-Community-Involvement--Word-274-kb-.doc

9. Stauskis, G. Darnios rekreacijos ir turizmo plètra - alternatyvaus mobilumo mieste skatinimo būdas = Development of Sustainable Recreation and Tourism as a Way of Promoting Alternative Urban Mobility. Urbanistika ir architektūra $=$ Town Planning and Architecture, Vol. 33, No. 1, 2009, p. 28-38. doi:10.3846/1392-1630.2009.33.28-38
10. Stauskis, G. Optimization of Urban Planning Model for Developing Health Care Network in Vilnius Regional Area. Urbanistika ir Architektūra = Town Planning and Architecture, Vol. 29, No. 1, 2005, p. 41-46.

11. Statement of Community Involvement and Plannign Applications [online]. Office of the Deputy Prime Minister. London [Cited 12.05.2012.]. http:// www.communities.gov.uk/corporate/

12. Turner, T. City as Landscape : A Post-Modern View of Design and Planning. London: Taylor \& Francis, 1995, p. 21-37. ISBN 0-419-20410-5

13. Vilnius City Housing Renovation Programme "Renovate the Housing Renovate the City" [online]. Renovacija [cited 15.05.2012.]. http://www. renovacija.lt/index.php/why_useful/about_the_programme/48n

14. Visuomenès dalyvavimo teritorijų planavimo procese nuostatai. Lietuvos Respublikos Vyriausybės 1996 m. rugsėjo 18 d. nutarimu Nr.1079 (Lietuvos Respublikos Vyriausybės 2004 m. liepos 16 d. nutarimo Nr. 904 redakcija) [online]. Lietuvos Respublikos Seimas [cited 15.05.2012.]. http://www3.lrs. lt/pls/inter3/dokpaieska.showdoc_1?p_id=237982\&p_query=\&p_tr2=

15. Walters, D. Designing Community. London: Taylor \& Francis, 2007, p. 135-159.

16. Urbonaitè, I. Urban Territorial Communities and their Influence Forming Urban Recreational Territories. Science - Future of Lithuania, Vol. 3, No. 3, 2011, p. 30-37.

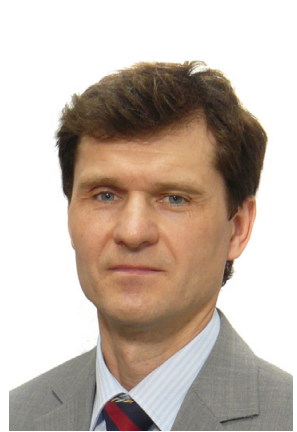

Gintaras Stauskis, Doctor of Humanities, Professor of Vilnius Gediminas Technical University conducting academic and research activities at the Department of Urban Design. He is involved in collaborative research programmes of the European Union. Current research fields: green architecture, sustainable urbanism, accessibility of environment, health care networks, urban recreation. Research results have been presented in numerous national and international publications and conferences.

\section{Contact Data}

Gintaras Stauskis

Vilnius Gediminas Technical University, Department of Urban Design

Address: Trakų g. 1/26, Vilnius, LT-01132, Lithuania

Work: +370 52370564

Mobile: +37068790312

Fax: +37052745213

E-mail: gintaras.stauskis@vgtu.lt

www.vgtu.lt 